\title{
Developing Inclusive Engineers: Teaching Peer-Mentors Principles of Equity and Inclusion
}

\section{Dr. Jennifer Harper Ogle, Clemson University}

Dr. Jennifer Ogle is a Professor in the Glenn Department of Civil Engineering at Clemson University, and a 2005 graduate of the Department of Civil and Environmental Engineering at Georgia Tech. Her research portfolio focuses on transportation infrastructure design, safety, accessibility, and management. She is currently the facilitator for the NSF Revolutionizing Engineering and Computer Science Departments (RED) grant at Clemson, and is leading three transformation efforts related to culture, curriculum, and community to achieve adaptability, innovation, and shared vision. Alongside her research, Dr. Ogle has been active in the development of engaged learning and has led two interdisciplinary undergraduate translational research and education courses - Clemson Engineers for Developing Countries (CEDC) and Clemson Engage. Both courses include trips to developing countries, international internships and significant fund-raising to support projects with community partners. As a result of her efforts, the CEDC program grew from 25 students to over 100 from 30 different departments and was recognized by the Institute for International Education (IIE) with the Andrew Heiskell Award. As a first generation student, and the first tenured female in her department, Dr. Ogle is an advocate for improving inclusion and diversity in Civil Engineering. In 2012, she was recognized by President Obama as a Champion of Change for Women in STEM. She continues to serve the university in diversity-enhancement programs including serving as the Chair of the President's Commission on Women and as a member of the ADA Commission.

\section{Ms. Candice W Bolding, Clemson University}

Candice Bolding (CJ) is currently the Undergraduate Student Services Manager in the Glenn Department of Civil Engineering and graduate student at Clemson University. She acts as a support to the undergraduate students in areas such as advising, programming, and registration. She also serves as the advisor to the Civil Engineering Student Advisory Council, which provides a voice for undergraduate students in the program and supervises department outreach student ambassadors. She currently sits on the department's Diversity and Outreach Committee and is a liaison for the department to the Office of the Associate Dean of Undergraduate Studies for the college.

\section{Juliann Ava Lloyd, Clemson University}

Juliann Lloyd works as a research assistant in the Civil Engineering Department at Clemson University. She is currently a participant in the BS/MS program and will graduate with a BS in Civil Engineering in May 2020. In August, she plans to begin a Ph.D. program in either Civil Engineering or Engineering Education. Juliann serves as a mentor in the department's CEMENT program, helps recruit new students while working as a Civil Engineering Ambassor and participates as a member of the Civil Engineering Student Advisory Council (CESAC).

\section{Mr. Logan C. Wade}




\section{Developing Inclusive Engineers: Teaching Peer-Mentors Principles of Equity and Inclusion}

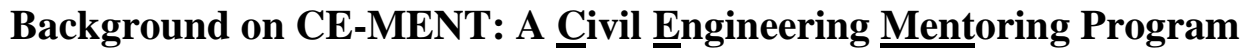

As part of an NSF IUSE/PFE:RED grant, the Clemson University Glenn Department of Civil Engineering instituted a peer mentoring program, called CE-MENT to attract and support students through a key transition point in the curriculum between general engineering and entry into the major. The program name has dual meaning, as cement is defined as a binding agent or something serving to unite firmly. As freshmen, underrepresented minorities and females are supported by the Programs for Educational Enrichment and Retention (PEER) and Women in Science and Engineering (WISE). However, these programs do not carry forward as students leave the common first year in General Engineering and move into their respective majors. Through the involvement of junior and senior engineering students as peer mentors for incoming sophomore students in the engineering department, the mentoring program provides valuable one-on-one guidance and contributes positively to the engineering community.

The peer mentoring program was formulated to foster interaction role modeling and interdependencies among students. Studies show that such interactions and interdependencies foster students' positive perceptions of their future selves in the profession [1]. The peer mentoring program provides the opportunity to create motivational preferences for collaboration, and to foster personal motivation for academic achievement. Specifically, the program sought to determine: the change in students' attitudes toward peer mentoring activities during their years of engineering study (from mentee to mentor); how participating in peer mentoring affects students' satisfaction with program experiences (i.e., transition, belonging, and academic success); and their intent to remain in the program.

\section{Early CE-MENT Program Assessment Data}

During Fall 2018, 112 potential mentees received a Qualtrics survey form via email and a total of 53 responses were received. Of the 53 responses, 44 students $(83 \%)$ participated in the program as mentees. Key measurements of the 5-point Likert scale survey assessed the effectiveness of the program in the areas of transition, belonging, and academic success. Overall, the majority felt that the mentor program helped their transition into the engineering program and increased their sense of belonging in the major. Interestingly, despite the lack of a formal tutoring aspect of the program, $41 \%$ percent of students felt that participation in the program positively contributed to their academic success. A new Student Assessment of Learning Gains (SALG) is being developed for the coming year for the mentors. Past mentor assessments have been provided in end of semester presentations and reflections. The SALG will supplement and not replace the presentation and reflection.

\section{CE-MENT Program Components and Operation}

At its inception in the first year of the grant, the peer mentor program had seven mentors. Over the past two-plus years, the program has grown significantly. Currently, there are 25 active mentors, many of whom were former mentees. The program is operating on a volunteer basis 
and credit is not provided to the mentees, so there is a wide range in level of involvement by mentees. On average, this year the mentees had 2 active mentees each given the volunteer nature of the program.

Over the last two years, a significant effort has been devoted to enabling mentors to build individual effectiveness, understand the power of critical thinking and communication, and embrace their own ability to lead within the engineering community. Mentors enroll in a special topics course that spans across the spring and fall semesters. The mentor programs kick-off occurs in the fall semester when the bulk of sophomore students ( 95 of 120-130 students per year). In the spring semester preceding the fall kick-off, new mentors apply and are selected for participation in the program. Soon after mentors have been selected, all mentors (old and new) are invited to participate in a welcome/farewell transition celebration. This is an exciting meeting for new mentors and hearing from the old mentors how the program has impacted their person development is motivating. Following the kick-off, students participate in a 1-cr hour online course to fulfill some of the mandatory mentor training and begin their person development journeys.

Minimum selection criteria include good standing in the university, no record of student misconduct, a GPA of 2.75, participation in any number of extracurricular activities on campus, and time availability within their course schedule to attend a face-to-face course in the fall semester and participate in the mentoring practicum. Students are also chosen to provide a wide representation of student identity, transfer students, first generation students, and non-traditional students. Most all students that have expressed an interest in the program have been selected to participate. Only one or two students have been requested to delay their participation due to coop rotations, extensive course loads, or need to focus on grades that would have precluded their full participation in the program.

\section{Mentor Role Domains, Constructs, and Training Modules}

Borrowing from Clemson University's President's Leadership Institute, the mentor course was designed to support and develop professional and personal leadership within a diverse and inclusive community of engineering students. The mentors are exposed to new ideas and participate in self-analysis and healthy discussion on a myriad of topics including personal leadership skills, team building, conflict resolution, critical consciousness, diversity and inclusion, advocating, privilege, Title IX, and strategic change. In the fall, the students participate in a two-hour course with one-hour being the mentoring practicum and the other allowing time for some of the more group-specific exercises and discussion to take place. Mentors work in both large and small groups as they engage with course material

Prior research summarizes the functional mentor roles, and for sake of expedient implementation of our mentoring program the framework, the domains and constructs were adopted directly [2] [3]. The training was developed to support the four mentoring domains: psychological and emotional support (PES), goal setting and career path (GSC), academic subject knowledge support (AKS), and the existence of a role model (ERM). Gunn, Lee, and Steed [3] found that for mentors, the role modeling factor was identified as most important, but for mentees, it was 
academic knowledge support followed by psychological and emotional support. Table 1 below lays out the domains, pertinent constructs, and associated training modules to develop student aptitude for these various mentor roles.

Table 1 Summary of mentor role domains, constructs, and associated training modules

\begin{tabular}{|c|c|c|}
\hline $\begin{array}{l}\text { Mentor Role } \\
\text { Domains }\end{array}$ & Typical Constructs & Training Modules \\
\hline $\begin{array}{l}\text { Psychological and } \\
\text { emotional support } \\
\text { (PES) }\end{array}$ & $\begin{array}{l}\text { - Listening } \\
\text { - Providing moral support } \\
\text { - Identifying problems } \\
\text { - Discussing fears and } \\
\text { uncertainties } \\
\text { - Accepting mentees } \\
\text { feelings } \\
\text { - Establishing a supportive } \\
\text { relationship } \\
\text { - Empathy }\end{array}$ & $\begin{array}{l}\text { Active Listening - mentors participate in } \\
\text { role-play to practice building good active } \\
\text { listening skills (listening does not mean } \\
\text { agreeing) } \\
\text { Care Reporting and Mandatory } \\
\text { Reporting - Students receive training on } \\
\text { reporting instances of abuse or self-harm } \\
\text { and learn about programs to help } \\
\text { students who are personally struggling } \\
\text { Reading and Perspective Taking Exercise } \\
\text { - White Priviledge: Unpacking the } \\
\text { Invisible Knapsack and Exercise } \\
\text { Why We Resist Diversity of Thought - } \\
\text { Reading and Reflection } \\
\text { Identity Training and Ally Training - } \\
\text { Students explore the many identifies of } \\
\text { students on campus and learn how they } \\
\text { can advocate for minority student groups, } \\
\text { create more inclusive spaces, and } \\
\text { cultivate the inclusive culture of our } \\
\text { department } \\
\text { Soup Ingredients - Students identify } \\
\text { what they are made of and make an } \\
\text { ingredients list on a soup can label }\end{array}$ \\
\hline $\begin{array}{l}\text { Goal setting and } \\
\text { career path (GSC) }\end{array}$ & $\begin{array}{l}\text { - Assessing mentees } \\
\text { strengths, weaknesses } \\
\text { and abilities } \\
\text { - Assist with setting goals } \\
\text { (academic and career) } \\
\text { - Helping monitor progress } \\
\text { to goals } \\
\text { - Assisting with planning } \\
\text { actions }\end{array}$ & $\begin{array}{l}\text { Career Center Field Trip - Usually the } \\
\text { first-time mentors have visited career } \\
\text { center and learn about services (mock } \\
\text { interviews, resume reviews) and } \\
\text { resources (salary database, free } \\
\text { professional clothing) } \\
\text { Career Fair Preparation - Mentors take } \\
\text { knowledge from a trip to the career }\end{array}$ \\
\hline
\end{tabular}




\begin{tabular}{|c|c|c|}
\hline & $\begin{array}{l}\text { - Networking and } \\
\text { cultivating social capital }\end{array}$ & $\begin{array}{l}\text { center and help mentees prepare to attend } \\
\text { and plan for internships, co-op, or future } \\
\text { jobs } \\
\text { Strengths Finder (Student) - Students } \\
\text { take an online quiz and reflect on ideas } \\
\text { for leveraging talents for achievement } \\
\text { Mentor-Mentee Contract Writing - } \\
\text { Defining desired outcomes of the } \\
\text { mentoring relationship and expectations } \\
\text { for the process } \\
\text { Event Participation - Mentors schedule } \\
\text { an outing to a professional organization } \\
\text { on campus and invite mentees } \\
\text { Advising } 101 \text { - a crash course in } \\
\text { everything you need to know to help } \\
\text { mentees take full advantage of advising } \\
\text { and get the courses they need and want } \\
\text { (including study abroad) }\end{array}$ \\
\hline $\begin{array}{l}\text { Academic subject } \\
\text { knowledge support } \\
\text { (AKS) }\end{array}$ & $\begin{array}{l}\text { - Support mentee academic } \\
\text { success } \\
\text { - Tutoring or helping } \\
\text { mentee seek tutoring } \\
\text { - Sharing mentee } \\
\text { accomplishments } \\
\text { - Shielding mentees after } \\
\text { shortcomings }\end{array}$ & $\begin{array}{l}\text { Tutoring Resource Overview - } \\
\text { Presentations from tutors and tutoring } \\
\text { programs on campus. Whom do they } \\
\text { serve and how do they operate? } \\
\text { Academic Success Center Field Trip - } \\
\text { Most mentors have never visited and are } \\
\text { amazed at the resources, coaching } \\
\text { services, accessibility services and } \\
\text { training available for free } \\
\text { Getting Things Done - Introducing the } \\
\text { Flow Map (one minute } \rightarrow \text { do it, longer } \\
\rightarrow \text { define and calendar the next step) } \\
\text { Time Tracking and the Brain Dump - } \\
\text { Getting all that stuff out of your head and } \\
\text { into your calendar and knowing how } \\
\text { much time you have available to } \\
\text { realistically give away } \\
\text { Teamwork - Mentors work through a } \\
\text { survival challenge game to understand }\end{array}$ \\
\hline
\end{tabular}




\begin{tabular}{|c|c|c|}
\hline & & $\begin{array}{l}\text { how diverse teams are typically found to } \\
\text { be better problem solvers }\end{array}$ \\
\hline $\begin{array}{l}\text { Existence of a role } \\
\text { model (ERM) }\end{array}$ & $\begin{array}{l}\text { - Sharing present and past } \\
\text { actions, achievements, } \\
\text { and failures } \\
\text { - Provide opportunities to } \\
\text { learn without hard knocks } \\
\text { - Strong relationship with } \\
\text { trust } \\
\text { - Symbiotic connections }\end{array}$ & $\begin{array}{l}\text { Integrity First - If you tell someone you } \\
\text { are going to do it...then do it! } \\
\text { DISC Assessment - Students take the } \\
\text { DISC and discuss how their actions and } \\
\text { words may be misconstrued by } \\
\text { individuals with different engagement } \\
\text { styles } \\
\text { Leading Strategic Change - Design } \\
\text { Thinking to Break Out of the Excuse, } \\
\text { "It's how we've always done things } \\
\text { here" } \\
\text { Leadership Reflections - Who do you } \\
\text { look up to as a leader? What do they do } \\
\text { that inspires you? } \\
\text { Leadership Readings - "Your } \\
\text { Company's Culture is Who You Hire, } \\
\text { Fire, and Promote", "Why good people } \\
\text { become bad bosses" } \\
\text { Values Exercise - Starting with } 100 \text { and } \\
\text { ending with a handful. What } 5 \text { values } \\
\text { most closely define you? } \\
\text { Dealing with Difficult People - Which } \\
\text { one are you most likely to be? Students } \\
\text { watch a short video on difficult people in } \\
\text { meetings and then brainstorm other } \\
\text { difficult scenarios that they have } \\
\text { encountered. In many cases, the difficult } \\
\text { person is just encountering stress and the } \\
\text { answer is Communicating with } \\
\text { Compassion (Ted Talk) }\end{array}$ \\
\hline
\end{tabular}

\section{CE-MENT Reflections}

Because the program is still developing, formal assessments of learning for every exercise do not yet exist. We are also working to capture how these training sessions are used by mentors in their mentoring and daily lives. However, mentors maintain a weekly journal and are required to write reflections with each course activity. These reflections are then used to provide feedback to the instructors at the end of the fall semester after the mentoring practicum takes place. The 
presentations typically focus on what resonated with the mentors and what may need to be changed, tweaked, or addressed with additional training. The comments below are a sampling of what students shared in their end of semester presentation and reflections.

- DISC Reflection - "Remember that although your tenacity is powerful, it may intimidate some."

- Empathy - "Engineering is hard, foundational classes are not collaborative, many have not ever experienced failure before college - Share a personal experience of overcoming difficulty"

- Privilege - "As a class, we discussed whether certain characteristics of a person gave them privilege or disadvantage. In some cases, we all agreed...but for many cases, we were split (ex. Glasses, mixed backgrounds, gender). This activity showed me that what some may see as a disadvantage, others may see as a privilege."

- Values - "As I am about to begin my career...I would like these values to be taken with me: honesty and integrity, dedication and commitment, focused determination, continued improvement - never settling"

- Identity Training - "I have a lot of pre-conceived notions of what opinions people around here have about gay people or anyone in the LGBTQ+ community. With that being said, I was interested to see what type of training Clemson provided...the mentors seemed to be very open to learning about the community. As for Clemson training, it was a lot more comprehensive than I was expecting...I think it is very important to bring awareness to the community and I am very happy that this is something that CE-MENT is participating in."

Countless reflection statements are indicating how this training helps our students develop into more conscious human beings - to see the disparities in our culture and to encourage more inclusive practices. Essentially, we not only hope that they will be good mentors to our incoming students and foster inclusion, equity and belonging within our department, but that they will take the lessons to their homes, neighborhoods, and future workplaces to help our world understand and value difference and create inclusive communities.

\section{Acknowledgement}

This work was supported through a grant from the National Science Foundation (Award: NSF IUSE/PFE:RED \# 1730576). Any opinions, findings, and conclusions or recommendations expressed in this material are those of the author(s) and do not necessarily reflect the views of the National Science Foundation.

\section{References}

[1] L. Benson, A. Kirn, and C. J. Faber, "CAREER: Student Motivation and Learning in Engineering," Paper presented at 2014 ASEE Annual Conference \& Exposition, Indianapolis, Indiana. https://peer.asee.org/20152, 2014. 
[2] G. Crisp, and I. Cruz, "Mentoring college students: A critical review of the literature between 1990 and 2007," Research in Higher Education, vol. 50, no. 6, pp. 525-545, doi:10.1007/s11162-009-9130-2, 2009.

[3] F. Gunn, S. Lee, and M. Steed, "Student Perceptions of Benefits and Challenges of Peer Mentoring Programs: Divergent Perspectives from Mentors and Mentees", Marketing Education Review, vol. 27, no. 1, pp. 15-26, DOI: 10.1080/10528008.2016.12555602017, 2017. 